\title{
Attempted Suicide Pact by Married couple: A Case Study
}

\author{
Risal A \\ 1. Associate Professor, Department Of Psychiatry, Kathmandu University Hospital, Dhulikhel, \\ Kavre, Nepal
}

E-mail *Corresponding author: $\underline{\text { drajayrisal@gmail.com }}$

\begin{abstract}
Suicide pact or a double suicide refers to the joint, actively induced death of two individuals at approximately the same time by mutual consent. News regarding these incidents is often found in media though scarcely published in medical literature. We report a psychiatric case history of a couple who attempted a suicide pact.
\end{abstract}

Keywords: Dyadic death, Homicide-suicide, Suicide pact

\section{INTRODUCTION}

Suicide pact or a double suicide refers to the joint, actively induced death of two individuals at approximately the same time by mutual consent. ${ }^{1-2}$ We often get media reports regarding these incidents; but they are rarely discussed in medical literature. ${ }^{2-5}$ Similarities and differences of suicide pacts from individual suicidal acts have been debated for last 50 years. ${ }^{5-7}$ Some regard homicidal quality to be the key factor in suicide pact; ${ }^{7}$ while other consider it to be typically absent. ${ }^{5}$ Literature has shown frequency of suicide pacts to be $0.6-4$ percent. ${ }^{4,5-6}$ They are usually found to be ironically associated with romantic, dramatic and colorful stories. ${ }^{7}$ The majority of suicide pact victims and survivors are married, socially isolated, with a serious physical or mental illness in one or both partners.1, 3,4, 6, 8-11 We report a psychiatric case history of a couple (husband and wife) who attempted an impulsive act of suicide pact.

\section{CASE HISTORY}

Mr. K, a 19 year male and Mrs. S, 20 year female were referred to psychiatry OPD of Dhulikhel Hospital, Kathmandu University Hospital from Medicine Department. Both of them, husband and wife, married for 1 year, were brought to Emergency department two days before. They were spotted by their relatives in unconscious state, at a place away from home. Empty bottles of 'Novan' (Organophosphorus compound) were found nearby.

Thinking it to be most likely case of attempted suicide pact, detailed history was taken from both of them separately and again in combination. Later corroborative history was attempted with their guardians ( $\mathrm{K}^{\prime} \mathrm{s}$ father and S's mother). Following Mental Status Examination, the Intentional Self Harm (ISH) attempted by the couple was considered to be an impulsive act of low intentionality and lethality; and possibility of personality disorder and mild depression was kept in mind. They were prescribed low dose SSRI (Sertraline 25mg) along with Risperidone $0.5 \mathrm{mg}$ and scheduled for Supportive Psychotherapy. 
As per the history, S, Bachelor in Management student, and K, 10+2 Science student, resident of the same village in Kavre, had been in love relationship for last 2-3 years. After the boy cleared $11^{\text {th }}$ standard and the girl passed $12^{\text {th }}$ standard, they decided to make the relationship permanent and social through marriage. Both their parent were aware of their relationship; but against their marriage, as the boy was younger to the girl and they were in different streams of education. However, constant pressure and threat made them reluctantly consent for the marriage.

As reported by K's father, $\mathrm{K}$ had always been of difficult temperament since childhood; stubborn and demanding, in comparison to his sister. $\mathrm{He}$ never complied with his parents' suggestion to study at Banepa, but went on choosing colleges from Bhaktapur to Kathmandu. He was staying with his unmarried sister in a rented flat at Banepa. Lately, he had been asking for a Motorbike or letting them take a room at Kathmandu as it would be easy to reach their colleges. Father was against this as he could not afford taking two different rented quarters, nor could he buy a Motorbike soon. These factors always brought quarrel in their home whenever they were together during weekends. Apart from these, there was no history of substance use or family history of suicide or any other mood/ psychotic illnesses.

S's mother, on the other hand, reported that S had been doing well in her studies and family/ social life. However, after exposure of her relationship with $\mathrm{K}$ in the family, she started becoming more arrogant and impulsive; and her academic performances started declining. When her parents decided not to let her marry K, she had threatened to end her life. She moved away from home and stayed at her maternal uncle's home. However, there was no history of substance use or family history of any kind of psychiatric illnesses.

After marriage, both $\mathrm{K}$ and $\mathrm{S}$ stayed in $\mathrm{K}^{\prime}$ s flat along with his sister. Constant tension was reported between these two ladies over household works. One day before the incident, there was small verbal quarrel between these two on the issue of dinner preparation. $\mathrm{K}^{\prime} \mathrm{s}$ father also shouted at $S$ for making a scene over trivial matter. Later, both of them ( $\mathrm{K}$ and $\mathrm{S}$ ) went out of home and took food in a restaurant.
The next morning, they went to Kathmandu (as usual in college time). After reaching Kathmandu, $\mathrm{K}$ suggested $\mathrm{S}$ not to attend the college. Both of them went for a movie but left the cinema hall before interval. Meanwhile, K asked $S$ if she was ready to go to Dolalghat which she accepted. K went to a seed shop asking $S$ to wait in the street. He bought two bottles of Novan.

When they were in the bank of river, $\mathrm{K}$ started crying bitterly in front of S. Suddenly, he asked if $\mathrm{S}$ loved him. $\mathrm{S}$ was amazed because of his sudden inquiry. Later, $\mathrm{K}$ told that family and society were against their love so they should die together on the spot to make their love immortal. He took out the bottles he had bought in the shop and suggested both of them take simultaneously.

According to $S$, though she was very much depressed with the incident the day before, she had never thought of committing suicide. She was not aware of what $\mathrm{K}$ had bought in the shop but she was worried something might have been going on in $\mathrm{K}^{\prime} \mathrm{s}$ mind as he had been mysteriously quiet throughout the day which was not typical of him. But, his sudden suggestion of ending their life together made her emotional and she took hold of the bottle and both of them consumed together. After consumption of small sip, S started vomiting while $\mathrm{K}$ was unconscious. A ringtone in $\mathrm{K}^{\prime} \mathrm{s}$ mobile made $S$ aware of the happenings around. She received the call, which was from K's maternal uncle. She became hopeful of life and told everything to the caller who came to rescue them and brought both of them to the hospital. Still, many more needs to open up to reach a definite diagnosis of the case which we hope to gain in subsequent psychotherapy sessions.

\section{DISCUSSION}

Suicide attempts are more common in young adults. ${ }^{4}$ It has been considered to be one of the commonest causes of untimely death among young people. ${ }^{12-13}$ Common methods of suicide are poisoning, hanging, drowning; rarer ones being jumping from a cliff, shooting or selfstabbing. ${ }^{14}$ They can occur as an isolated episode or as a form of dyadic deaths. $8,10,14$

Suicide pact needs to be differentiated from the other forms of "Dyadic death"; i.e., suicide clusters, accidental deaths of relatives associated 
with suicide gesture of another person, simultaneous suicide (independent decision of close friends suffering from depression), mass suicides (in those involving cults) 8; and Homicide-suicide (actively induced death of two or more individuals without the consent of the other, as in family suicide). 2, 3 An essential feature of suicide pact is the mutual consent ${ }^{9-10}$; but as it cannot always be clinically differentiated from homicide-suicide, recent studies do not distinguish between the two.2,11

Though daily newspapers bring the incidents of suicides by frustrated individuals, childless couples, disappointed lovers or family suicide related to poverty or economic hardship in media, they are rarely reported in medical journals. ${ }^{3}$ It may be due to the fact that when both parties die, investigations are usually carried out by the police and law rather than by medically trained personnel and medicos are uncomfortable interviewing survivors of pacts and/or their families. ${ }^{7}$

Analysis of available literature revealed that frequency of suicide pacts to be greatest in Japan; mostly lovers' pacts. ${ }^{15}$ Majority of such pacts in the West were of husbands and wives ${ }^{1,7}$; while in India, friends' pacts were the maximum. ${ }^{15}$ No medical report of such pacts has been found in Nepali medical literature. In the last three years (June 2010-June 2013), in Dhulikhel Hospital, we came across 242 cases of Intentional Self Harm (89 cases in last 6 months, January to June 2013), two of the studies related to suicide are published ${ }^{16-17}$; but this was the first incident of attempted suicide pact we came across, which was spouses' pact.

High degree of mutual social isolation, termed as "encapsulated unit"; which might be the only substrate for their entire social life, has been frequently observed circumstance in most of the double suicide cases. ${ }^{18}$ This kind of mutual dependence is capable of turning every external threat to the unit (due to the critical events like loss of home, health deterioration or rejection of relationship) into the factor which may provoke the joint suicide. ${ }^{2,}, 7,14,19-20$

Although such pact is generally carried out by mutual consent, one of the partners (who is dominant in the relationship, commonly male) usually induces the action and is the one actively carrying out the action in most cases.2, 7, ${ }^{9}$ In our case, the husband $(\mathrm{K})$ was the active member and initiator of the pact. Sometimes, suicide pacts have also been found to occur between complete strangers after negotiation through the internet which is called as internet suicides. ${ }^{10,}, 21$

Mental disorder is common in those who enter suicide pacts, usually the inducer; and the relief of mental disorder (with or without external stressor), pain and fear of dissolution of the dependent relationship, are considered to be the main motivation behind such pacts. ${ }^{1,} 4$, 9 Some studies have shown depression and substance use disorder common in those pact attempters ${ }^{1}$; while others show high prevalence of borderline and narcissistic personality traits. ${ }^{2}, 9$ In our report, most probably the husband has impulsive traits along with depression and the wife has borderline traits; and the couple would benefit from psychotherapeutic interventions along with low dose antidepressants.

As with any kind of psychiatric illnesses, suicide in general and suicide pact in particular, are both influenced by the cultural background and social factors. ${ }^{2}, 22$ In our case, the couple with emotionally unstable personality traits having family and social situation in which love marriage was not well accepted, might have been the predisposing factor to decide to end their life together in a place away from home.

\section{CONCLUSION:}

Health professionals in general and psychiatrists in particular, need to assess the risk of suicide pact especially while encountering any couple sharing dependent relationship and presenting with any emotional issues that is likely to threaten integrity of such relation. The uniqueness and rarity of suicide pact makes it more challenging to understand why such incident happened.

\section{ACKNOWLEDGEMENT:}

We would like to thank Ms. Yasoda Bajagain, CMA, Department of Psychiatry and nursing students (BNS 2nd Batch and BSc. Nursing $9^{\text {th }}$ Batch) for helping in preparing this case-report. 


\section{REFERENCES:}

1. Brown M, King E, Barraclough B. Nine Suicide Pacts -A Clinical Study of a Consecutive Series 1974-93. British Journal of Psychiatry 1995; 167: 448-51.

2. Haenel T, Elsasser PN. Double Suicide and Homicide-Suicide in Switzerland. Crisis 2000; 21:122-5.

3. Latha KS. Suicide pact survivors: some observations. Med. Sci. Law 1996; 36 (4): 295-8.

4. Hocaoglu C. Double suicide attempt. Singapore Med J 2009; 50(2): 81-4.

5. Cohen J. A study of suicide pacts. Medico-legal Journal 1961; 29: 144-51.

6. Brown M, Barraclough B. Epidemiology of suicide pacts in England and Wales, 1988-92. BMJ 1997; 315:286.

7. Rosenbaum M. Crime and PunishmentThe Suicide Pact. Arch Gen Psychiatry 1983; 40:979-82.

8. Prat S, Rerolle C, Saint-Martin P. Suicide Pacts: Six Cases and Literature. Review J Forensic Sci (Internet).2013 (doi: 10.1111/1556-4029.12056).

onlinelibrary.wiley.com. (Last accessed on 9/7/2013).

9. Rosen BK. Suicide pacts: a review. Psychol Med 1981; 11(3):525-33.

10. Rajagopal S. Suicide pacts and the internet. BMJ 2004; 329(7478):1298-9.

11. Cohen D, Llorente $M$, Eisdorfer C. Homicide-suicide in older person. Am J Psychiatry 1998; 155(3):390-6.

12. Diekstra RF, Gulbinat W. The epidemiology of suicidal behavior: a review of three continents. World Health Stat Q 1993; 46:52-68.

13. Vijaykumar L. Suicide and its prevention: The urgent need in India. Indian J Psychiatry 2007; 49(2): 81-4.

14. Rastogi $P$, Nagesh KR.Suicide pact by hanging. Med Sci Law 2008; 48 (3):266-8.

15. Fishbain DA and Aldrich TE. Suicide pacts: international comparisons. J. Clin. Psychiatry 1985; 46 (1), 11-5.

16. Risal A, Sharma PP. Psychiatric manifestations of patients admitted for intentional self harm. Journal Inst. Med. 2011; 33 (1): 43-8.

17. Risal A, Sharma PP, Karki RK. Psychiatric Illnesses among the Patients
Admitted for Self-poisoning in a Tertiary Care Hospital of Nepal. Journal Adv. Int. Med 2013; 02(01):10-3.

18. Hemphill RE, Thornley FI. Suicide pacts. S Afr Med J 1969; 43:1335-8.

19. Noyes R Jr, Frye SJ, Hartford CE. Conjugal Suicide Pact. J. Nerv. Ment. Dis. 1977; 165 (1), 72-5.

20. Brown M, Barraclough B. Partners in life and in death: the suicide pact in England and Wales 1988-1992. Psychological Medicine 1999; 29 (06): 1299 $-1306$.

21. Haines L. Seven dead in net suicide pact. Japanese police probe web link. (Internet) 2004. http://www.theregister.co.uk/2004/10 $\angle 12 /$ net_suicide_pact $\quad$ (Last accessed on 9/7/2013).

22. Marcikic M, Vuksic Z, Dumencic B, Matuzalem E, Cacinovic V. Double Suicide. Am J Forensic Med Pathol 2011; 32: 200-1. 